\title{
СОСТАВ ГАЗООБРАЗНЫХ ПРОДУКТОВ ТЕРМОЛИЗА КАК ДИАГНОСТИЧЕСКИЙ ПРИЗНАК ГЕНЕТИЧЕСКОГО ТИПА КАУСТОБИОЛИТА
}

\author{
(Представил О. Эйзен)
}

В ходе систематического исследования горючих сланцев различных месторождений было установлено, что состав газа полукоксования этих каустобиолитов характеризуется определенным своеобразием и отличается от состава газообразных продуктов, образующихся при термическом разложении твердых горючих ископаемых иного генетического типа.

Одной. из отличительных особенностей газа термического разложения сланцев является повышенная непредельность его углеводородной части. Поскольку состав газа существенно зависит от режима термолиза $\left[{ }^{1,2}\right]$, для получения сравнительных данных термическое разложение должно проводиться в одинаковых условиях. В настоящей работе рассматриваются газообразные продукты, образующиеся при полукоксовании в стандартной алюминиевой реторте по ГОСТу 3168-66, т. е. при нагреве до $520^{\circ} \mathrm{C}$ и при отсутствии доступа воздуха.

На рисунке приведены данные о непредельности газа полукоксования сланцев, а для сравнения аналогичные данные для некоторых горючих ископаемых других генетических рядов в зависимости от атомного соотношения $\mathrm{H} / \mathrm{C}$ в органической массе топлива, являющегося одним из показателей, характеризующих тип осадочного органического вещества. Горючие сланцы, бурые угли, каменные угли, липтобиолиты и подобные им неординарные каустобиолиты группируются в использованных координатах в довольно четко разграниченных областях. При этом типичные горючие сланцы, имеющие преимущественно липиднолипоидное (по [$\left.\left.{ }^{3}\right]\right)$ происхождение, располагаются обособленно от сланцев смешанной природы (диктионемовый ЭССР, менилитовый УССР, кварнторпский Швеции и др.). Хотя степень катагенетической превращенности последних, как и других сланцев, обычно не превышает буроугольной, а в качестве имеющей нелипидное происхождение части их органического вещества часто принимается материал гумусового начала, области таких сланцев и бурых углей разделены областями собственно горючих сланцев и липтобиолитов. Таким образом, по составу газообразных продуктов разложения органическое вещество бурых углей и составляющая смешанных керогенов, которая не берет начало от липидного материала, существенно различаются; последняя, по-видимому, в большинстве случаев представляет собой белково-углеводный продукт, т. н. меланоидиновые вещества или амикагины.

Если наряду с данными о предельности углеводородов учесть также некоторые другие данные о составе газов полукоксования, отдель- 


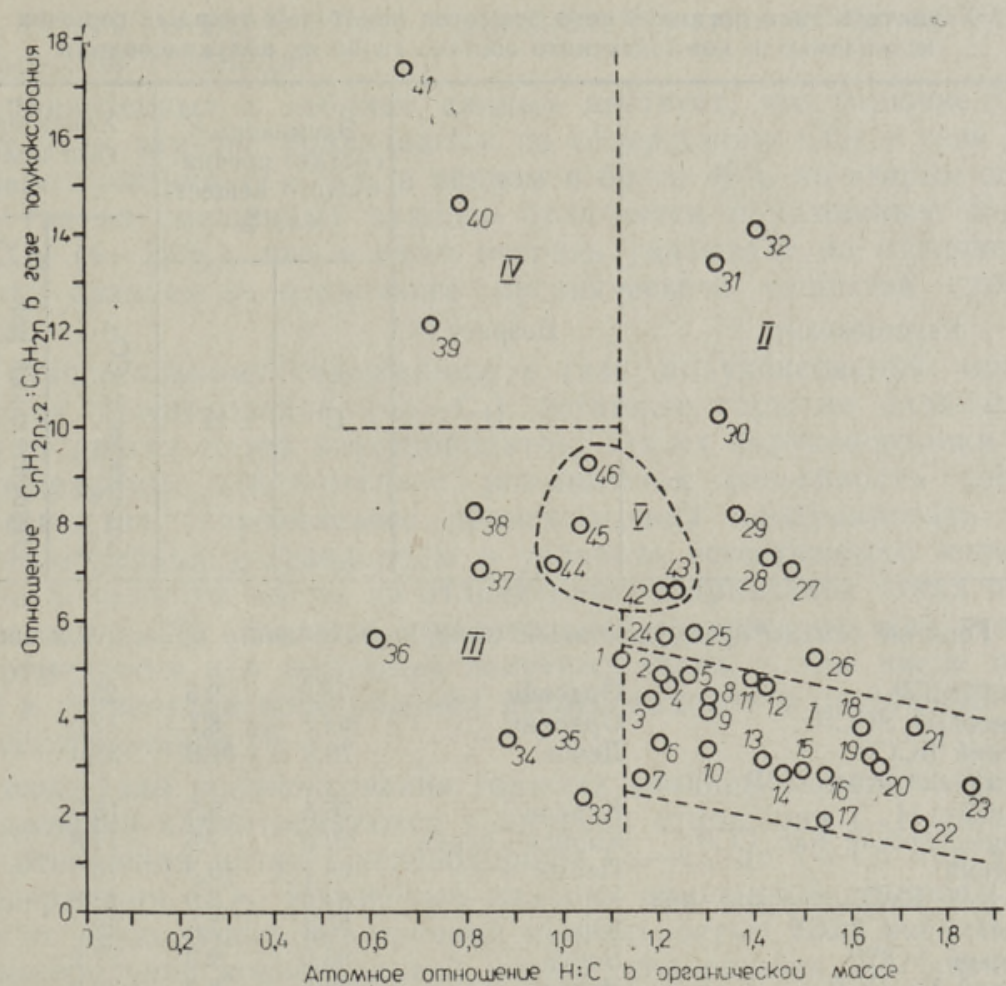

Зависимость предельности углеводородной части $\left(\mathrm{C}_{n} \mathrm{H}_{2 n+2}: \mathrm{C}_{n} \mathrm{H}_{2 n}\right)$ газов полукоксования каустобиолитов от атомного отношения $\mathrm{H} / \mathrm{C}$ в их органической массе.

I - область горючих сланцев преимущественно липидно-липоидного происхождения: памукский Уз. ССР $(i)$, сангрунтауский $У_{3}$. ССР (2), чандырский $\mathrm{У}_{3}$. ССР (3), кульялийский Тадж. ССР $(4)$, гарибакский Тадж. ССР (5), култак-зевардынский Уз. ССР (6), усть-каменогорский Каз. ССР (7), 'кендерлыкский Каз. ССР, пласт «Калын-Кара» (8), кендерлыкский, пласт «Лучший» $(9)$, ухтинский юрский Коми АССР $(10)$, байсунский Уз. ССР (11), кашпирский Куйбышевской обл., кровля (12), кашпирский, пласт II (13), кукерсит (14), кендерлыкский, пласт «Средний» (15), общесыртовский Куйбышевской обл. (16), будаговский Иркутской обл. (17), тетрасписовый ЭССР (18), болтышский УССР (19), воронье-волосковский Кировской обл. (20), ново-дмитровский УССР $(21)$, припятский БССР (22), месторождения Ирати, Бразилия (23);

II - область нетипичных (смешанных) сланцев: ухтинский девонский Коми АССР (24), месторождения Сэнт-Илер, Франция (25), хахарейский Иркутской обл. $(26,27)$, босонский, Франция $(28)$, менилитовый УССР $(29)$, кванторпский, Швеция (30), диктионемовый ЭССР, месторождение Тоолсе $(31)$, диктионемовый ЭССР, месторождение Маарду (32); III - область бурых углей: александрийский УССР (33), новодмитровский УССР (34), будаговский Иркутской обл. (35), канскоачинский Красноярского края $(36)$, жилкинский Иркутской обл. $(37,38)$ : IV - область каменных углей: донецкий «Г» (39), витринит кузнецкого угля «Ж» $(40)$, донецкий «ПЖ» $(41)$; V - область липтобиолитов и близких к ним каустобиолитов: жилкинский богхед Иркутской обл. (42), черемховский уголь Иркутской обл. (43), хахарейский «смоляной» уголь Иркутской обл. (44), дальневосточный рабдописсит (45), грузинский липтобиолит (46). 
Характеристика органического вещества некоторых твердых горючих ископаемых и компонентного состава газов их полукоксования

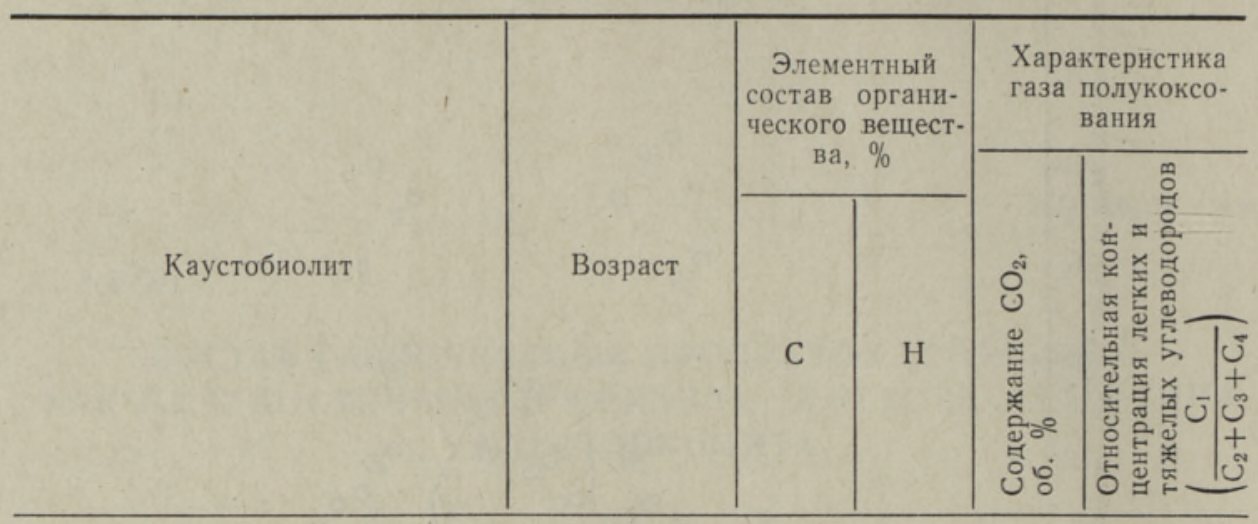

Горючие сланцы преимущественно липидно-липоидного происхождения

Кукерсит ЭССР

Тетрасписовый ЭССР

Припятский БССР

Кендерлыкский Каз. ССР (пласт «Средний»)

Усть-каменогорский Каз. ССР

Бразильский

Кашпирский Куйбышевской обл.

Ухтинский Коми АССР

Болтышский УССР

Байсунский Уз. ССР

Гарибакский Тадж. ССР

Ново-дмитровский УССР

\section{Ордовнк \\ Ордовик \\ Девон}

Карбон Карбон-пермь
Пермь

Юpa

Эоцен

Эоцен

Эоцен

Палеогеннеоген

$\begin{array}{rrrr}78,2 & 9,5 & 25,2 & 0,68 \\ 64,5 & 8,7 & 12,5 & 0,86 \\ 79,9 & 11,6 & 23,0 & 0,22 \\ 76,6 & 9,5 & 15,9 & 0,65 \\ 77,6 & 7,5 & 17,8 & 0,53 \\ 68,1 & 10,3 & 16,1 & 0,72 \\ 67,0 & 8,0 & 23,8 & 0,80 \\ 70,1 & 7,6 & 22,3 & 0,68 \\ 68,0 & 9,3 & 27,2 & 0,57 \\ 68,8 & 8,0 & 28,9 & 0,86 \\ 63,9 & 6,7 & 35,6 & 1,43 \\ & & & \\ 69,3 & 10,0 & 31,8 & 1,26\end{array}$

Горючие сланцы смешанного происхождения

Кварнторпский, Швеция

Диктионемовый ЭССР (Маарду)

Диктионемовый ЭССР (Тоолсе)

Босонский, Франция

Хахарейский. Иркутской обл.

Менилитовый УССР

Будаговский Иркутской обл.

Жилкинский Иркутской обл.

Канско-ачинский Красноярского края

Александрийский УССР

Ново-дмитровский УССР

Донецкий уголь «Г»

Донецкий уголь «ПЖ»

Витринит кузнецкого угля «Ж»
Кембрий

Ордовик

Ордовик

Карбон

Юра

Олигоцен

Бурые угли

$\begin{array}{lllll}\text { Юра } & 71,3 & 5,7 & - & 2,41 \\ \text { Юра } & 71,5 & 5,0 & 55,5 & - \\ \text { Юра } & 72,4 & 4,9 & 60,1 & 2,37 \\ \text { Эоцен } & 68,2 & 5,9 & 42,4 & - \\ \begin{array}{l}\text { Палеоген一 } \\ \text { неоген }\end{array} & 70,6 & 5,2 & 54,6 & 1,65\end{array}$

Каменные угли

Карбон
Карбон
Пермь

$\begin{array}{rrrr}69,5 & 7,7 & 8,0 & 1,89 \\ 70,5 & 8,3 & 16,8 & 2,70 \\ 69,0 & 7,6 & 15,4 & 1,87 \\ 77,0 & 9,2 & 4,2 & 3,46 \\ 67,2 & 7,0 & 21,8 & - \\ 68,2 & 6,9 & 16,0 & 2,45\end{array}$

1,87

3,46
2,45

ные виды каустобиолитов можно различать и без привлечения сведений об элементном составе их органической массы. Наиболее характерными из таких показателей являются концентрация двуокиси угле- 
рода в газе и относительное содержание метана и более тяжелых углеводородов (таблица).

Из приведенных в таблице данных явствует, что горючие сланцы и бурые угли заметно различаются по содержанию $\mathrm{CO}_{2}$ в газе термического разложения ( $4-35 \%$ в первом и более $40 \%$ во-втором случае), причем газ из смешанных сланцев отличается пониженным содержанием $\mathrm{CO}_{2}(4-22 \%)$, что в свою очередь указывает на отличие керогена этих сланцев от осадочного органического вещества гумусовой природы.

По относительному содержанию в газе полукоксования метана и «тяжелых» углеводородов $\left(\mathrm{C}_{2}-\mathrm{C}_{4}\right)$ истинные горючие сланщы отличаются от других видов каустобиолитов: газ их полукоксования обогащен последними. Действительно, повышенная способность органического вещества сапропелевого происхождения продуцировать «тяжелые» газообразные углеводороды в условиях естественного катагенеза известна и является одним из отличительных признаков таких отложений (см. напр., $\left.\left[{ }^{4}\right]\right)$. Высокое относительное содержание этих углеводородов отмечается и в нефтяных попутных газах, в том числе приуроченных к региону распространения исследованного в настоящей работе белорусского сланца [5].

В целом газы полукоксования горючих сланцев липидно-липоидного происхождения характеризуются величиной отношения $\mathrm{C}_{n} \mathrm{H}_{2 n+2}: \mathrm{C}_{n} \mathrm{H}_{2 n}$ до 5 и отношения метан : углеводороды $\mathrm{C}_{2}-\mathrm{C}_{4}$ до $1-1,5$ при умеренном содержании $\mathrm{CO}_{2}$. Изученные сланцы смешанной природы отличаются от предыдущих повышенной предельностью газа и более высокой относительной концентрацией метана; содержание $\mathrm{CO}_{2}$ низкое.

Таким образом, состав газа полукоксования, являющийся отражением химического строения каустобиолита, в то же время характеризует генетический тип последнего. Учитывая, что для установления состава газа термического разложения ископаемого органического вещества требуется немного материала и анализ в случае использования газохроматографического метода несложен, данный показатель можно рекомендовать в качестве диагностического при изучении органического вещества осадочных пород. Поскольку при очень низких концентрациях органического углерода в породе определенное влияние на состав газа полукоксования могут оказать вторичные реакции превращения адсорбированной минеральной частью сланцевой смолы [ $\left.{ }^{6}\right]$, в случае рассеянного органического вещества вышеуказанные наблюдения целесообразно проверить на соответствующих образцах.

\section{Л И ТЕРАТ УРА}

1. Аронов С. Г. Использование газовых углей для коксования. Харьков - M., 1949.

2. Jacobson, I. A., Decora, A. W., Cook, G. L. Retorting indexes for oil-shale pyrolysis from ethylene-ethane ratios of product gases. - Rept. Invest. Bur. Mines. U. S. Dep. Inter., 1974, N 7921.

3. Г усев а А. Н., Л й фм ан И. Е., В а с соевич Н. Б. К биогеохимии липидов, липондов и родственных полимерных соединений. - В кн.: Исследования органического вешества современных и ископаемых осадков. М., 1976, с. 25-26.

4. Ив анов В. В., Клубов Б. А. Нафтиды и нафтоиды Северо-Востока СССР. M., 1979.

5. Кудельский А. В., Бурак В. М., Цыганов а С. У. Газовый режим нефтяных месторождений Белоруссии. - В кн.: Геологическое изучение территории Белоруссии. Минск, 1979 , с. $122-128$. 
6. У ров К. Э., Клесмент И. Р., Высоцкая В. В. О зависимости состава и свойств органического вещества горючих сланцев от его содержания в породе (на примере сланцев Кашпирского месторождения). - В кн.: Всесоюзное совещание «Геохимия горючих сланцев». Тез. докл. Таллин, 1978, с. 94-96.

Ннститут химии

Академии наук Эстонской ССР
Поступила в редакцию 14/XII 1979

K. UROV

\section{TERMILISE LAGUNEMISE GAASIDE KOOSTIS KUI KAUSTOBIOLIIDI GENEETILISE TUUBI DIAGNOSTILINE TUNNUS}

Artiklis on esitatud seisukoht, et süsivesinikosa küllastatuse, metaani ja raskemate süsivesinike suhtelise kontsentratsiooni ning süsinikdioksiidi sisalduse alusel tahkekütuste uttegaasides on võimalik ligikaudselt määrata kaustobioliidi geneetilist tüüpi.

K. UROV

\section{COMPOSITION OF THERMAL DESTRUCTION GASES AS A DIAGNOSTICAL FEATURE OF THE GENETIC TYPE OF A CAUSTOBIOLITH}

On the basis of the alkane : alkene, the methane : $\mathrm{C}_{2}-\mathrm{C}_{4}$ hydrocarbons ratios and the concentration of carbon dioxide in gases formed by semicoking of fossil organic material, it is possible to tentatively determine the genetic type of a caustobiolith. 